\title{
Application of Pesticide Phytoremediation in Irrigated Rice Fields System Using Eceng Gondok (Eichhornia crassipes) Plants
}

\author{
Ika Kartika Febriani $^{1,}{ }^{*}$ and Hadiyanto ${ }^{1,2}$ \\ ${ }^{1}$ Master Program of Environmental Science, School of Postgraduate Study Diponegoro University \\ ${ }^{2}$ Chemical Engineering Dept, Faculty of Engineering, Diponegoro University
}

\begin{abstract}
The problem of environmental pollution especially urban water pollution becomes major issue in Indonesia. The cause of water pollution is not only from industrial factory waste disposal but also other causes which become pollution factor. One cause of water pollution is the existence of agricultural activities with the use of the amount of pesticides that exceed the threshold. As regulated in Government Regulation No. 82/2001 on Water Quality Management and Water Pollution Control, it is necessary to manage water quality and control water pollution wisely by taking into account the interests of current and future generations as well as the ecological balance. To overcome the problem of water pollution due to agricultural activities, it is necessary to conduct research on phytoremediation technique by utilizing eceng gondok plant. It is excepted that using this phytoremediation technique can reduce the problem of water pollution due to the use of pesticides on agricultural activities.
\end{abstract}

\section{Introduction}

Problems of environmental pollution, especially the problem of water pollution in cities in Indonesia is quite serious. The cause of water pollution is not only from industrial factory waste disposal but also other causes which become pollution factor. One cause of water pollution is the existence of agricultural activities that exceed the threshold. Namely excessive use of pesticides. The use of pesticides in agriculture has increased since agricultural intensification programs were proclaimed by the government in 1970. Even most farmers already depend on pesticides. They assume that pesticides are the saviors of pest attacks. Farmers use pesticides with doses that are sometimes incompatible with the procedure. They do not know what the impact will be on the environment if pesticides are used excessively.

Pesticides that are not absorbed by plants will return to nature. So it becomes a residue that is quite detrimental to the environment. The residue settles on the ground and is carried by water to the river. Then the river water polluted by the residue was reused by farmers to irrigate their fields. So the residue was reabsorbed by plants, especially rice plants that need water that pooled during its growth. To overcome the problem of water pollution in rice fields due to pesticide residues, farmers can use eceng gondok as a heavy metal absorber carried by water. Eceng Gondok is one of the floating aquatic plants that have the Latin name Eichhornia crassipes. This plant is often regarded as a weed that destroys the aquatic ecosystem because of its fast growing nature and easily spread from one body of water to another body of water.

Eceng gondok is one type of aquatic plant that has the ability to absorb and accumulate heavy metals. This plant has the potential to absorb heavy metals because it is a plant with high tolerance that can grow well in waste, rapid growth and absorb and accumulate metal well in a short time. Eceng gondok can also reduce the value of Biological Oxygen Demand (BOD), Total Suspended Solid (TSS) and Chemical Oxygen Demand (COD) of liquid waste [1]. Eceng gondok absorbs heavy metals using Phytoremediation Technique. Phytoremediation is a process involving chlorophyll plants to reduce the pollutant content present in soil, air and water [2]. Phytoremediation is a technique that uses plants to reduce or decrease the levels of pollutants in the environment so that it becomes harmless [3]. Phytoremediation is gaining attention because it is one of the alternative technologies to clean up the environment from pollutants, especially for soil and water, because it is considered effective, efficient, more economical and sustainable [4].

There are several categories in phytoremediation: phytoextraction, phytofiltration, phytostabilization,

\footnotetext{
Corresponding author: ikakf@yahoo.com
} 
phytovolatization, and phytodegradatio depending on their remediation mechanism [5].

Phytoextraction involves the use of plants to remove contaminants in the soil. Pytofiltration is the process of removing metals from water contaminated by plant roots or plants. While phytostabilization involves the roots to absorb pollutants from the soil and store them in the rhizosphere, and reduce the spread of pollutants. Phytovolatization involves the use of plants to remove pollutants through the evaporation process in leaf foliage, as in $\mathrm{Se}$ and $\mathrm{Hg}$ pollutants. Pyhtodegradation is the use of plants to associate with microorganisms in reducing levels of pollutants [6].

\subsection{Eceng gondok plant}

Eceng gondok (Eichornia crassipes) is a water plant that grows in swamps, lakes, reservoirs and rivers that flow calmly. Historically, water hyacinth in Indonesia was brought by an American botanist to the Bogor Botanical Garden. Due to rapid growth (3\% per day), water hyacinth is able to cover the entire surface of a pond. According to Hadiyanto et al [7] explains that water hyacinth is a weed plant in aquatic area that lives floating in deep water or develops rooting in mud in shallow water. Hyacinth multiply very quickly, both vegetatively and generatively. Proliferation by vegetative means doubled twice within 7-10 days.

The proliferation of eceng gondok occurs vegetative and generative, vegetative propagation occurs when new shoots grow from the leaf's armpits, then enlarge and eventually become new plants. Every 10 hyacinth plants are capable of breeding to 600,000 new plants within 8 months, this is what makes water hyacinth used for wastewater treatment.

The ability of eceng gondok is much so that it is used to treat waste water, because human activity is capable of processing domestic waste water with a high level of efficiency. Eceng gondok can reduce BOD, suspended particles biochemically (lasts a bit slowly) and is able to absorb heavy metals such as $\mathrm{Cr}, \mathrm{Pb}, \mathrm{Hg}$, $\mathrm{Cd}, \mathrm{Cu}, \mathrm{Fe}, \mathrm{Mn}, \mathrm{Zn}$ well, the ability of absorbing heavy metal union of eceng gondok at a young age than in old age.

\subsection{The Benefits Of EcengGondok}

Water hyacinth causes a lot of problems of river and reservoir pollution, but has the following benefits [8] : It has a biological nature as a water filter contaminated by various industrial-made chemicals; As a cover material, compost in agriculture and plantation activities; As a gas source, among others, ammonium sulphate gas, hydrogen gas, nitrogen and methane obtained by fermentation; Raw material of plant fertilizer containing NPK elements which are the three main elements needed by plants; As an industrial material of artificial board paper and activated carbon materials.

\subsection{Loss of Eceng Gondok}

Adverse conditions that arise as a result of uncontrolled growth of eceng gondok are: The decrease of the amount of light entering into the water causes the decreasing of oxygen solubility in water (DO: Dissolved Oxygen); Disrupt traffic (transport) of water, especially for people whose lives are still dependent from the river; Increased habitat for human disease vector and decrease aesthetic value of aquatic environments.

\subsection{Absorption by Eceng Gondok}

This plant has a rapid regeneration power because the pieces of vegetative pieces that carry will continue to develop into adult eceng gondok. Eceng gondok is very sensitive to the conditions in the water that the element is insufficient, but its response to high levels of nutrients is also large, causing eceng gondok can be used as a controller of environmental pollution. Plant root cells commonly contain ions with a higher concentration than the normally negatively charged surrounding medium. This absorption involves energy, as a consequence and its existence, the cation shows the passive entry into the cell passively into the electrochemical gradient, while the anion must be transported actively into the root cell of the plant according to the gradient state of concentration against the electrochemical gradient.

The root part, the ordinary plant changes the $\mathrm{pH}$ and forms a chelate called fitosiderofor. It is this substance that then binds the metal and is then brought into the root cell. In order for the absorption of metals to increase, then this plant to form the redottase molecule in the root membrane. While the transport model in the plant body is the metal brought into the root cell then to the transport network of xylem and phloem, go to other plants, while the localization of metal on the network aims to prevent metal poisoning against the cell, the plant will do detoxification, such as stockpiling of metals into certain organs such as roots. There are two ways of ion absorption into plant roots: The mass flow of ions in the water moves rapidly toward the potential gradient roots caused by transpiration; concentration gradient diffusion is generated by ion removal at the root surface.

In the absorption of these ions there are two important things that must be considered, namely first, the metabolic energy needed in the absorption of nutrients actually a little nutrients, resulting in respiration. Second, the collection process is selective, the plant has the ability to select the absorption of certain ions in wide environmental conditions.

\section{Heavy Metal}

Heavy metals are dangerous water pollutants, including $\mathrm{Pb}, \mathrm{Cu}, \mathrm{Hg}$ and $\mathrm{Cd}$. Various cases of pollution by $\mathrm{Pb}$, $\mathrm{Cd}, \mathrm{Hg}$ and $\mathrm{Cu}$ have been widely reported, because heavy metal ions can cause poisoning in humans. 
Severe damage to the kidneys, liver, brain and central nerves and inhibits $\mathrm{Hb}$ synthesis. There are 80 species of 109 chemical elements on earth that have been identified as heavy metals. From a toxicological point of view, these heavy metals can be divided into two types. First, the essential heavy metal, where its presence in a certain amount is needed by living organisms, but excessive amounts can have toxic effects. Examples of these heavy metals are $\mathrm{Zn}, \mathrm{Cu}, \mathrm{Fe}$, $\mathrm{Co}, \mathrm{Mn}$ and others, while the second type is nonessential heavy metals or toxic, where its presence in the body is still unknown or even toxic, such as $\mathrm{Hg}$, $\mathrm{Cd}, \mathrm{Pb}, \mathrm{Cr}$ and others.

\subsection{Heavy Metal Pollution}

Water contamination occurs when the substance of the condition (including heat) lowers the quality of the water body so that water can't meet the standard quality or can't be used for a particular purpose [8]. Pollution of heavy metals present in the soil, water and air with a mechanism of entry into living things. Heavy metals that enter into the human body will interact with other enzymes, proteins, DNA, and other metabolites. The presence of heavy metals in the body will obviously affect the body. When the amount is excessive, it will be harmful to the body. Pollution of heavy metals into the environment can be through three ways, namely:

\subsubsection{Water}

Water pollution occurs in water sources of lakes, rivers, oceans and ground water caused by human activities. Water is said to be contaminated if it can't be used according to its function. This pollution can be caused by industrial waste, housing, agriculture, household, industry and fishing by using poison. Industrial pollutants include organic pollutants (wastewater), inorganic pollutants (solids, heavy metals), fuel residues and kerosene spills are sources of water pollution, especially ground water. Water pollutants include chemical elements, pathogens and changes in the physical and chemical properties of water. Many chemical elements are toxins that contaminate water.

Water pollution is a regional and global environmental problem and is closely related to air pollution and land or land use. Water pollution consists of various types, and their effects on the environment and living things. One of the causes of water pollution is the presence of inorganic chemicals such as $\mathrm{Pb}, \mathrm{Cd}$ and $\mathrm{Hg}$. The presence of metal toxic substances such as $\mathrm{Pb}, \mathrm{Cd}, \mathrm{Hg}$ in high levels cause the water is not good for consumption.

\subsubsection{Soil}

Pollution is mostly caused by waste, both organic and inorganic. Substances of waste that seep into the soil can't be lost for long periods of time. The waste substances that enter the soil are absorbed by the plant and remain in the plant's body, because the plant can't decipher it. Industrial waste that pollutes the soil is usually excessive fertilizer and the use of herbicides and pesticides.

The content of heavy metals in the soil greatly affect the metal content of plants growing on it, unless there is interaction between the metal so that the metal absorption occurs by the plant. The accumulation of metals in plants depends not only on the content of metals in the soil, but also depends on soil chemical elements, metal types, soil $\mathrm{pH}$, and plant species.

\subsubsection{Air}

Air pollution is caused by exhaust fumes such as $\mathrm{CO} 2$, $\mathrm{SO}, \mathrm{SO} 2, \mathrm{CFC}, \mathrm{CO}$ and cigarette smoke. Pollutants can come from factories, machines that use fossil fuels and from burning wood.

\subsection{Heavy Metal Pollution in the Waters}

Heavy metal pollution in many waters is sourced from mining, metal smelting, and other types of industries [9]. Heavy metals are usually found very little in water naturally less than $1 \mu \mathrm{g} / \mathrm{l}$. To determine the water quality to the concentration of metal in dissolved therein. Concentrations of toxic metals such as $\mathrm{Cd}, \mathrm{Pb}$, $\mathrm{Hg}$ and $\mathrm{As}$ in waters are naturally very small. The presence of heavy metals in the water, dangerous directly to the life of the organism, as well as its effects indirectly to human health. Heavy metals are chemical elements of a type greater than $5 \mathrm{gr} / \mathrm{cm}^{3}$, located in the lower right corner of the periodic system, have a high affinity for the element $\mathrm{S}$ and are usually atomic number 22 to 92 from the period of 4 to 7 . Some heavy metals such as Lead $(\mathrm{Pb})$, cadmium $(\mathrm{Cd})$, and mercury $(\mathrm{Hg})$ are harmful pollutants. The high affinity of the $\mathrm{S}$ element causes this metal to attack the sulfur bond in the enzyme, so that the enzyme becomes inactive.

Many heavy metals, both toxic and essential, dissolve in water and contaminate both fresh and marine water. The source of this pollution comes largely from mining, smelting metal, and other types of industries, and can also come from agricultural land using fertilizer containing metals. In water the metal is usually bonded in a chemical compound or in the form of an ionic metal, depending on the compartment on which the metal is located. The degree of metal content in each compartment varies considerably, depending on location, type of compartment and level of contamination. It has been widely reported on the concentrations of metals in water and living biota therein. Usually the concentration levels of heavy metals in water are differentiated according to the level of pollution, heavy pollution, medium pollution, and non polar. A waters with heavy pollution levels usually contain heavy metals in water, and the organisms that live in them are quite high. At a moderate level of pollution, the heavy metal content of water and biota 
living within it are within marginal limits. While at the non polar level, the heavy metal content in water and organisms that live in it is very low, even undetected.

\section{Phytoremediation}

The term phytoremediation comes from English phytoremediation; The word itself is composed of two parts of the word, the phyto derived from the Greek phyton ("plant") and remediation derived from the Latin remedium ("heal", in this case also means "solving the problem by fixing the error or deficiency"). Thus phytoremediation can be defined as the use of plants to remove, move, stabilize, or destroy the contaminants be it organic or inorganic compounds Alternative simple wastewater treatment is by phytoremediation using eceng gondok plant. Phytoremediation is the use of plants and their parts for waste decontamination and environmental pollution issues either ex-situ using artificial or reactor ponds or in-situ (direct field) on soil or contaminated areas of waste.

The method used is experimental method (experiment). While the experimental design used in this study was Completely Randomized Design (RAL) with 4 treatments and 3 replications.

Treatment design:

A: Control (Without Phytoremediation)

B: 5 eceng gondok / bucket

C: 8 eceng gondok / bucket

D: 10 eceng gondok / bucket

Then taken a sample of polluted water from several fields. Samples taken as many as 4 random stamps on several fields. Sample 1 is a water seal that has not yet entered the rice fields and water that has not been contaminated with pesticides. Sample 2 is water from a rice field that is close to irrigation. Then sample 3 is water from the rice fields in the middle. And the 4th is the water sample from the rice field plot leading to irrigation. For example illustration can be seen in the picture :

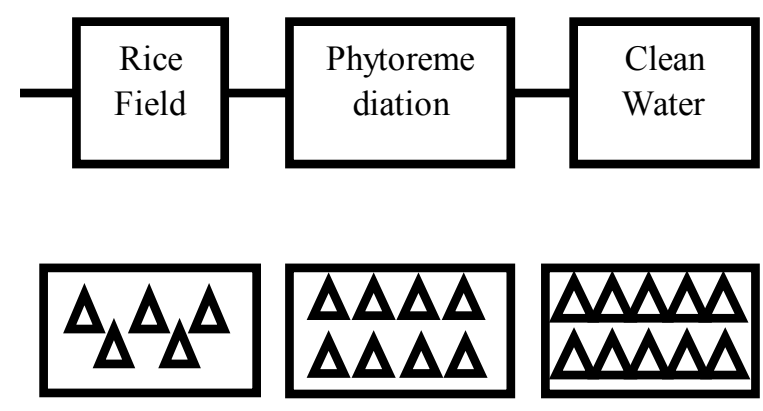

Fig. 1.Phytoremediation process

\section{Conclusions}

From the above reviews it can be concluded that agricultural activity is one of the pollution factors that occur in the environment, especially in the waters. To overcome this problem it must be phytoremediation so that the waters are not polluted by agricultural residues. Eceng gondok is selected as a plant for phytoremediation in waters contaminated by pesticides.

\section{References}

1. S.Kris, and Wariningsih. Jurnal Teknologi Technoscientia, Vol. 4 No 1. Hal : $17-22$, (2011).

2. Zayed. Journal Environmental Quality,Vol. 27: 715-721, (1998).

3. Lahenda, Shelga Sapta. Ellyke. Khoiron,E-Jurnal Pustaka Kesehatan, Vol. 3 No. 2, (2015).

4. Chaney, R.L., Malik, M., Li, Y.M., Brown, S.L., Brewer, E.P., Scott Angle, J., Baker, A.J.M.. Curr. Opin. Biotechnol, Vol. 8(3):279-284, (1997).

5. D.E. Salt, R.D. Smith, L. Raskin. Plant Mol. Biol". Vol. 49 (1):643-668, (1998).

6. M.I. Lone, Z. He, P.J. Stoffella, X. Yang, Journal Of Zhejiang University SCIENCE B, Vol. 9(3):210-220, (2008).

7. H. Hadiyanto, M. Christwardana, D. Soetrisnanto, Journal of Environmental Science and Technology,Vol. 6(2):79-90, (2013). 